\section{War Agricultural Committee}

Trie Minister of Agriculture and Fisheries has appointed a War Agricultural Executive Committeo for each county in England and Wales and has made an Order (The Cultivation of Lands Order, 1939) authorizing these committees to exercise on his behalf certain powers conferred on him by the Defence Regulations for the purpose of increasing home food production in time of war. In a Circular Letter to the committees, the Ninister states that they will be given as free a hand as possible to proceed as a matter of urgency with all possible steps to increase the production of foodstuffs in their areas. Their immediate task is to see that additional land is brought under the plough with all speed. The aim is to obtain for next year's harvest an increase of about $1 \frac{1}{2}$ million acres in the tillago area in England and Wales compared with the acreage in June last. Each county has been allotted its share of this total, and the committees have been urged to seo that every effort is made to complete their allotted tasks-and, if possible, to exceed them. Tho committees havo already been holding informal meetings and have made good progress with their preparatory work.

\section{Roman Temple at Albury, Surrey}

Romano-British studies aro greatly indebted to the Surrey Archæological Society for the work of excavation and conservation which has been carried out on the site of the Roman temple on Farley Heath, Albury, Surroy, by A. W. G. Lowther and R. G. Goodchild on behalf of the Society. The complete plan of the building has now been traced, and marked out by stones from the original structure, bedded in concrete. The site has been known for a long time. It attracted the attention of Elias Ashmole; and in 1670 and 1847 it was despoiled of much of its stone. Little, howrever, was known of its structure or its relation to surrounding buildings, if any. Recent excavation has shown, it is reported in The Times of August 18, that the temple consisted of a simple cella, or shrine, measuring $18 \mathrm{ft}$. internally, and surrounded by a corridor, or veranda, $8 \mathrm{ft}$. wide. It has been too much damaged for any details of the architecture to be known, but red tesserae and red wall plaster hint at the character of the internal decoration. It stood within a polygonal wall, approximately $240 \mathrm{ft}$. in diameter, which probably was intended to demarcate the sacred enclosure. An inner enclosing wall has been found on the north side. Few smaller antiquities have been found in the recent excavations, the most important being a fragment of a terra-cotta "votive lantern", similar to those found at Ashstead, Surrey, and Verulamium. The ground had been too thoroughly turned over by previous diggers to make it probable that many of the smaller class of objects would be found. Further, the excavations of 1848 had provided a rich spoilmore than 1,000 coins, mostly Roman, but including some rare British in gold and silver, and numerous enamelled brooches, while a thin strip of bronze, crudely embossed with human and animal figures, has since been identified as a pagan priest's ritual sceptre. The foundations of the temple were of local ironstone and chalk from the North Downs, but the superstructure was of Bargate sandstone. Wealden clay had been used for the tiles, baked, in all probability, in the tile-kiln discovered in 1936 in Wykehurst Farm, Cranleigh, four miles away.

\section{Archrological Explorations in the United States}

A Deterinination to limit public expenditure and opposition to the President in the United States of America have recently eliminated most of the intellectual activities which had been subsidized out of Federal funds in the desiro to stimulate prosperity by State aid. Archæological investigations in the field, however, so long as they worked within the States, have survived attack owing to the fact that they provide occupation for a considerable number of the unemployed. This consideration does not affect expeditions working abroad and in the old World, and these have had to be curtailed on the ground of economy. Nearly one hundred archxological expeditions, it is reported by Science Service of Washington, D.C., have taken the field in the course of the present summer; and of these, thirtytwo in twenty-two States aro financed as part of the W.P.A. programme, the Government supplying the labour-2,500 men and women in all-for excavation work under the direction of representatives of museums, universities and scientific institutions sponsoring the respective expeditions. Two investigations in particular have been made possible by the advantageous conditions. Of these, ono is a combined effort on the part of the Universities of Montana, Wyoming, and other of the south-western States to find evidence of the line of advance of the earliest immigrants into America through tho Siberia-Alaska gateway towards the south-west. The other will make a rapid and intensive examination of the mounds and other relics of early occupation in the vast region in the States of Tennessee, Alabama and Texas, which is marked for inundation when the dams of the Tennessee Scheme of water supply are built. It is hoped that it may be possible to trace the relation of the cultures of the Mississippi Valley to those of the south before it is too late, and the evidence disappears for ever.

\section{Excavations at Caerleon}

Furtuer excavations on the site of the Roman fortress of Caerleon-on-Usk have been necessitated by building development on two acres at the northeast angle. Evidence for the defences here, it is reported by Lady Fox, who directed the excavation on behalf of the Caerleon Excavation Committee (The Times, Aug. 5), comprised the primary clay bank and ditch of the occupation by the Second Augustan Legion in A.D. 75, and the foundations of the stone walls and one of the internal turrets set up about A.D. 100, when tho internal early timber buildings were reconstructed in stone. The con. struction of the rampart roadway, which provided access throughout the circuit of the fortress behind the ramparts, was examined. A block of barracks, 
set in pairs, back to back, and providing accommodation for soldiers, with more spacious quarters for the centurions, was found to $b \theta$ in plan similar to those excavated in the south-west corner of the fortress in 1926-9. A coin of Nerva confirmed the date of their erection. Occupation by the Second Legion on this occasion appears to have been short; but in the third century the barracks were thoroughly renovated at a date indicated by the stamp "Leg. II Aug. Anto." as A.D. 212-222. Relics of the latest occupation, not necessarily of a military character, were found in the centurions' quarters, where a tile hearth had been built over a destroyed partition wall, and the moulded base of a column, upside down and partly sunk in the floor, appears to have served as a gaming-table, as several counters wero found around it. The associated layers contained fourth century coins and pottery of a late type. In all, 70 coins wero found and 90 legionary stamped tiles. Pottery was not abundant, but the most interesting find was a hoard of fivo gold coins, ranging from two of Nero, A.D. 55 and 61 to Titus and Domitian, A.D. 74 and 73 , which was found concealed in a barrack floor, and possibly represents the savings of a soldier, which was left behind when the legion was ordered north.

\section{Health Activities of the Rockefeller Foundation}

THE annual report for 1937 of the International Health Division of the Rockefeller Foundation, recently published, gives an account of the projects carried out under the auspices of the Health Division by members of its staff. Virus agents of yellow fever, influenza and other diseases, and cortain proteins, including visual purple, have been studied by the use of an analytical ultracentrifuge. By means of a cultured yellow fever virus, a vaccine has been produced with which some 60,000 persons have been inoculated, mostly in Brazil, tho results of which show that a practicable safe method of Iarge-scale immunization against yellow fever is now available. Studies on the epidemiology of the jungle form of yellow fever have also been pursued. Tuberculosis, particularly in Jamaica, hookworm disease in Egypt and tho United States, and malaria and its mosquito vectors in various countries, are other subjects that have been investigated. In addition to research work, the Foundation renders financial aid to State and local health services and to health education in all parts of the world. The report, which is very readable, includes soveral plates illustrating the work carricd out.

\section{The International Seismological Summary}

THE International Seismological Summary for July, August and September 1933 has just come to hand, containing details of the calculations of the initial times and epicentres of 169 earthquakes. Sixty-eight of these epicentres are new and 101 aro repetitions from old epicentres, showing the tendency of earthquakes to recur from the same epicentre. Included in the 169 earthquake shocks are 15 which had a focal depth below normal, the deepest being that of August 29, 1933, with epicentre $11 \cdot 0^{\circ} \mathrm{S}$.,
$69 \cdot 5^{\circ} \mathrm{W}$. (in Bolivia near its junction with Peru and Brazil) and focus 0.085 of the earth's radius below normal. Twelve of these deep focus shocks had their epicentres between $45 \cdot 4^{\circ} \mathrm{N}$., and $20 \cdot 5^{\circ} \mathrm{S}$. latitude, and between $131.5^{\circ} \mathrm{E}$. and $170 \cdot 0^{\circ} \mathrm{E}$. longitude, thus showing the deep-seated instability of this region of the earth which has Japan in its north-west corner.

\section{Milk for Mothers and Children}

A schene was prepared a short time ago by the Milk Marketing Board and approved by the Minister of Agriculture and Fisheries for the supply of cheap milk to local authorities, and was outlined in a circular issued by the Ministry of Health (Circular 1840. H.M. Stationery Office. 3d. net). The aim of the scheme is to enable expectant and nursing mothers and children under five, who cannot afford the full retail price for the milk they need, to obtain a pint of milk per head per day either free or for not more than twopence according to family circumstances. Those wishing to receive milk under the scheme will have first to apply to the local authority and they will then be told whether they are eligible to receive the supply. When authorized, they will ask an approved dairyman to deliver at their homo the milk to which thoy aro entitled.

\section{Announcements}

The remainder of the meetings of the British Association which began in Dundee on August 30 were cancelled on September 1. Most of the members present left Dundee on that day.

TuE French Academy of Medicine has awarded the Grand Prix Prince Albert $\mathbf{I}$ de Monaco to Jules Lefèvre, for his work on biology during the last fifty years.

ON the occasion of the jubilee of the Paris Pasteur Institute the scientific and executive committees of the Institute have awarded the gold Pasteur Medal to Dr. H. Plotz, of New York, and Prof. A. Saenz, of Montevideo, for their contributions to science.

IT is announced in Aesculape of May that three now chairs for the history of medicine have been founded in Italy, namely, at Florence, Turin and Sienna, while corresponding chairs in Rumania have been abolished.

DR. W. JuNK writes from The Hague to point out a mistako in Dr. W. T. Calman's review of tho British Muscum reprint of Linnæus's "Systema Naturae" (Nature, August 12, p. 269). The tenth edition was not, as there stated, the last published during Lin. næus's lifetime. The twelfth edition began publication in 1766, twelve years before the death of the author.

Arr the poisonous snakes and insects in the Zoological Gardens of the Zoological Society of London have recently been destroyed. Several of the more valuable animals have been sent to Whipsnade. The Zoo is again open to the public. 